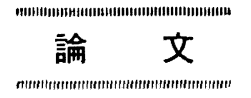

UDC $\quad 541.8: 541.123 .38: 669.15-192: 669.786$

\title{
溶融鉄の水素溶解度に及ぼす $\mathrm{Al}, \mathrm{B}, \mathrm{Ge}, \mathrm{Ta}, \mathrm{Sn}$ および Zr 添加の影響*
}

萬谷志郎**.不破裙**

\author{
The Effect of $\mathrm{Al}, \mathrm{B}, \mathrm{Ge}, \mathrm{Ta}, \mathrm{Sn}$ and $\mathrm{Zr}$ on the Solubility of \\ Hydrogen in Liquid Iron
}

Shiro BAN-YA and Tasuku FUWA

\begin{abstract}
Synopsis :
The solubility of hydrogen in liquid iron alloys has been studied by Sieverts' method at the temperature range from $1548^{\circ}$ to $1672^{\circ} \mathrm{C}$ and under an atmospheric pressure of hydrogen. The solubility of hydrogen in liquid iron decreases by the addition of $\mathrm{B}, \mathrm{Ge}, \mathrm{Al}, \mathrm{Sn}$, and $\mathrm{Ta}$, and increases by the addition of $\mathrm{Zr}$.

Interaction parameters at $1600^{\circ} \mathrm{C}$ are:

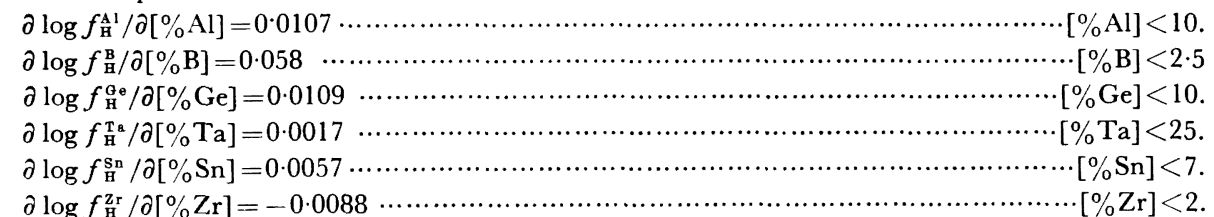

(Received Nov. 28, 1973)

\section{1. 緒言}

製鋼過程において溶鋼中に溶解した水素は，その鋼材 の性質に種々有害な影響をあたえるため，製鋼過程にお ける溶鋼中水素の物理化学的挙動について多くの與味が もたれてきた．著者らは鉄一水素系における物理化学的 基礎資料をうるため, Sieverts の測定法を改良し，水素 1 気压の下における溶鉄および 2,3 の溶融鉄合金の水 素溶解度を測定し，溶鉄中水素の活量係数におよほす合 金元素の影響を求める一連の研究 ${ }^{122)}$ を行なつてきた. 本報告では，その後引き続き測定を行なつた， $\mathrm{Fe}-\mathrm{Al}$, $\mathrm{Fe}-\mathrm{B}, \mathrm{Fe}-\mathrm{Ge}, \mathrm{Fe}-\mathrm{Ta}, \mathrm{Fe}-\mathrm{Sn}$ および $\mathrm{Fe}-\mathrm{Zr}$ 系の結果 について報告し，さらに，これまでの結果をまとめて比 較検討した.

\section{2. 実 験 方 法}

本研究は金属のガス溶解度測定法の1つである $\mathrm{Sie}-$ verts 法により，水素 1 気圧下における鉄合金の水素溶 解度を測定したものであり，すでに著者らの前報1で実 験装置, 実験方法, Sieverts 法の問題点, 本装置の特性
について詳細に記述したので，ここでは概略を記述する ことにする.

\section{$2 \cdot 1$ 実験装置}

実験装置は, 反応管, ガス量定量装置, ガス精製装置 および真空排気装置よりなる. 反応管は外径 $52 \mathrm{~mm} の$ 透明石英製で, 水冷二重壁になつており, 冷却水出口の 水温を $35^{\circ} \pm 1^{\circ} \mathrm{C}$ になるよう水量を調節する. 実験温度 に打ける反応管内実容積 (hot volume) を小さくするた め反応管内上部を細く絞り, 溶解試料を入れたるつほ は，さらに石英製保護るつほに入れ，その間をマグネシ ア粒 (20〜30mesh)，アルミナ製円板，ベリリア製円板 などを用いて充填する. 溶解用加熱炉は $8 \mathrm{KVA}$ 真空管 式高周波炉を使用し, 温度測定は反応管上部小孔より光 高温計を用いて行なう. 試料を溶融した状態における本 装置の反応管内実容積は, 室温にて 80 $85 \mathrm{ml}$, 測定温 度 $1450^{\circ} \sim 1670^{\circ} \mathrm{C}$ の範囲では $45 \sim 50 \mathrm{~m} l$ である.

* 昭和 45 年 4 月本会譜演大会にて発表 昭和48年11月28日受付

** 東北大学工学部 工博 


\section{$2 \cdot 2$ 試料および使用材料}

溶解試料として, 鉄分には電解鉄を真空溶解し, 径 15 $\mathrm{mm}$ に鍛造した丸棒を, 合金元素は市販の純金属(純度, $\mathrm{Al}>99.99 \%, \mathrm{~B}>97 \%, \mathrm{Ge}>99.99 \%, \mathrm{Ta}>99.9 \%$, $\mathrm{Sn}>99 \cdot 9 \%, \mathrm{Zr}>98 \cdot 5 \%)$ を使用した. これらの添加元 素は，あらかじめ測定目標組成に配合し，水素気流中で $2 \mathrm{hr}$ 以上溶解して試料中の酸素を十分に除去し，その約 $50 \mathrm{~g}$ を1 回の溶解試料とした。

実験温度における反応管内実容積 (hot volume) 測定 用不活性ガスとしては，熱伝導度が水素汇最も近いへリ ウムを，また水素は電解水素を用い，打の打の十分に精 製してガス中不純物を除去して使用した.

るつぼは内径 $16 \mathrm{~mm}$, 高さ $50 \mathrm{~mm}$ であり, 実験室で作 製した純粋なライムるつぼを，また $\mathrm{Fe}-\mathrm{Al} ， \mathrm{Fe}-\mathrm{B} ， \mathrm{Fe}-$

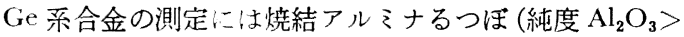
98\%）を使用した。

\section{3 試料化学分析}

溶解試料の化学組成は, 測定終了後の試料の化学分析 により决定した. $\mathrm{Fe}-\mathrm{Al}$ 合金中のアルミニウムはオキシ ム分離重量法, 研素はアルカリ融解一硼素酒石酸バリウ ム法, ゲルマニウムは硫化水素分離-酸化重量法, タン タルは亜硫酸ナトリウムータンニン分離重量法, ジルコ ニウム流 JIS 燐酸塩法をそれぞれ使用した。錫の定量 は十分な結果が得られなかつたため, 配合量と蒸発量よ り計算によつて求めた， $\mathrm{Fe}-\mathrm{B} ， \mathrm{Fe}-\mathrm{Ge}, \mathrm{Fe}-\mathrm{Ta}, \mathrm{Fe}-\mathrm{Zr}$ 系では測定前後における合金元素の濃度に大きい变化は 認められないが，Fe-Al，Fe-Sn 系では蒸発による合金 元素の濃度変化が著しく，アルミニウムでは 10～15\%， 錫では測定条件により 30〜70\% の濃度低下が認められ た.これらの系における化学組成は測定終了時の濃度を もつて合金元素の濃度とした。

\section{4 実験操作}

溶解試料 $50 \mathrm{~g}$ を反忘管内に設置し，まず $1 \sim 2 \mathrm{hr}$ 水 素気流中にて溶解する．この間 1 2 回反応管内を真空 に排気して反応管内を十分置換する.次いでガスが出な くなるまで 15〜20 min 真空に排気後（反応管内最終真 空度 $10^{-3} \sim 10^{-4} \mathrm{mmHg}$ ) ヘリウムを反応管内に導入し て, 各実駼温度における反応管内実容積 (hot volume) を求める.つぎにへリウムを排気後再び水素を導入して 各温度における水素導入量を測定する. 不活性ガスは溶 融金属中に溶解しないので，水素導入量とへリウム導入 量の差より各温度における水素溶解量が求められる. 反 応管内にガスを導入した場合，10〜15 min 後には安定 した一定值が得られるから，最も低い実駼温度より測定 を開始し，30〜 $40 \mathrm{~min} こ ゙ と に ~ 50^{\circ} \mathrm{C}$ ずつ温度を上げて
各温度における水素吸収量を測定後, 再び最低測定温度 に下ほて測定值の確認を行なう. 大部分の測定では前後 の值はよく一致するが， $\pm 0.5 \mathrm{ml}$ 以上の差のあつた場 合には，反応管内で副次反度がおきたものとして再実験 を行なつた

以上の方法により $1548^{\circ} \sim 1672^{\circ} \mathrm{C}$ の温度範囲で，合 金元素については可能なかぎり広い濃度範囲で，水素 1 気圧下に打ける水素溶解度を測定した，その測定值の再 現性は前報において述べたように，ほほ $\pm 1 \mathrm{ml} / 100 \mathrm{gFe}$ である。

\section{3. 実 験 結 果}

溶融金属中の水素が水化物を生成せず単純溶解する場 合の反応式拈よび平衡定数 $K_{\mathrm{Fe}}$ は，次の(1)，(2) およ び(3)式で示される. また純鉄については Sieverts の法 則が成立するゆえ，純鉄側を基準にした溶鉄中水素の活 量係数におよぼす合金元素 $\mathrm{j}$ の影響 $\mathrm{f}_{\mathrm{H}}^{\prime}$ は次式の関係か ら求められる.

$$
\begin{aligned}
& 1 / 2 \mathrm{H}_{2}(\mathrm{~g})=\underline{\mathrm{H}} \text { (in liquid iron) } \\
& K_{\mathrm{Fe}}=a_{\mathrm{H}} / V \overline{P_{\mathrm{H}_{2}}} \fallingdotseq[\% \mathrm{H}] / \sqrt{P_{\mathrm{H}_{2}}}
\end{aligned}
$$$$
\text { (純鉄の水素溶解) }
$$

$$
K_{\mathrm{Fe}-\mathrm{j}}=[\% \mathrm{H}] / \sqrt{P_{\mathrm{H}_{2}}} \quad(\text { 合金系の水素溶解) } \cdots
$$

$\log \mathrm{f}_{\mathrm{B}}^{\jmath}=\log K_{\mathrm{Fe}}-\log K_{\mathrm{Fe}-\mathrm{j}}$

$$
=\log [\% \mathrm{H}]-\log \left[\% \mathrm{H}^{\prime}\right]
$$

ただし

$a_{\mathrm{H}}:$ 溶鉄中水素の活量

$K_{\mathrm{Fe}-j}:$ 合金系における見掛けの平衡定数

$P_{\mathrm{H} 2}:$ ガス相中水素分圧 $(\mathrm{atm})$

$[\% \mathrm{H}]$ : 溶鉄の水素溶解度 (重量\%)

$\left[\% \mathrm{H}^{\prime}\right]$ : 合金系の水素溶解度 (重量\%)

\subsection{Fe-Al 系溶蠤合金の水素浴解度}

$\mathrm{Fe}-\mathrm{Al}$ 系溶融合金についてアルミニウム濃度 $17 \cdot 3 \%$ まで測定した水素溶解度の結果を Fig. 1 および Table 1 に示す. $\mathrm{Fe}-\mathrm{Al}$ 系溶融合金の水素溶解度は，アルミニウ 么の濃度を原子分率 (atom fraction， $X_{\mathrm{j}}$ ) で示せば 0.3 $X_{\mathrm{Al}}$ まで值線的に減少する. $\mathrm{Fe}-\mathrm{Al}$ 系平衡状態図汅は固 体状態で $\mathrm{Fe}_{3} \mathrm{Al}\left(0 \cdot 25 X_{\mathrm{Al}}, 14 \% \mathrm{Al}\right)$ の金属間化合物が 存在するが， $900^{\circ} \mathrm{C}$ 以上では消失し，溶融状態における 水素溶解度は単調な变化を示す. 本系についてはサンプ リング法による前川・中川(6)らの測定および Sieverts 法 による WEINSTEIN and ELLIOTT ${ }^{3)}$, 染野·長崎·門井4), 加藤·福田・椙山・古川5)らの測定があり，これらを Fig. 1 中に図示したが，著者らの測定結果は加藤ららの測定に 近い傾向を示している.

これらの測定結果より，著者らの前報の純鉄水素溶解 
Table 1. Solubility of hydrogen in iron-aluminium alloys under an atmospheric pressure.

\begin{tabular}{|c|c|c|c|c|c|}
\hline \multirow{2}{*}{ Heat No } & \multicolumn{2}{|c|}{ Concentration } & \multicolumn{3}{|c|}{ Solubility of hydrogen $(\mathrm{m} l / 100 \mathrm{~g})$} \\
\hline & $\% \mathrm{Al}$ & $X_{\mathrm{A} 1}$ & $1548^{\circ} \mathrm{C}$ & $1610^{\circ} \mathrm{C}$ & $1672^{\circ} \mathrm{C}$ \\
\hline $\begin{array}{lr}\text { A } 1 & 4-3 \\
\text { A } 1 & 5-3 \\
\text { A } 1 & 5-2 \\
\text { A } 1 & 5-1 \\
\text { A } 1 & 15-2 \\
\text { A } 1 & 10-4 \\
\text { A } 1 & 10-1 \\
\text { A } 1 & 10-3 \\
\text { A } 1 & 10-2 \\
\text { A } 1 & 15-3 \\
\text { A } 1 & 15-1 \\
\text { A } 1 & 20-1\end{array}$ & $\begin{array}{c}3 \cdot 42 \\
6 \cdot 76 \\
7 \cdot 14 \\
7 \cdot 73 \\
9 \cdot 13 \\
10 \cdot 1 \\
13 \cdot 0 \\
13 \cdot 2 \\
13 \cdot 8 \\
14 \cdot 4 \\
15 \cdot 7 \\
17 \cdot 3\end{array}$ & $\begin{array}{l}0 \cdot 068 \\
0 \cdot 130 \\
0 \cdot 137 \\
0 \cdot 148 \\
0 \cdot 172 \\
0 \cdot 189 \\
0 \cdot 236 \\
0 \cdot 239 \\
0 \cdot 247 \\
0 \cdot 258 \\
0 \cdot 278 \\
0 \cdot 302\end{array}$ & $\begin{array}{l}25 \cdot 04 \\
22 \cdot 20 \\
23 \cdot 47 \\
22 \cdot 14 \\
21 \cdot 35 \\
22 \cdot 57 \\
19 \cdot 77 \\
20 \cdot 30 \\
19 \cdot 00 \\
19 \cdot 16 \\
18 \cdot 98 \\
17 \cdot 86\end{array}$ & $\begin{array}{l}26 \cdot 75 \\
23 \cdot 92 \\
25 \cdot 26 \\
23 \cdot 65 \\
23 \cdot 51 \\
24 \cdot 34 \\
21 \cdot 56 \\
22 \cdot 02 \\
21 \cdot 11 \\
21 \cdot 56 \\
21 \cdot 01 \\
19 \cdot 74\end{array}$ & $\begin{array}{l}28 \cdot 46 \\
25 \cdot 63 \\
26 \cdot 96 \\
25 \cdot 32 \\
25 \cdot 78 \\
26 \cdot 12 \\
23 \cdot 36 \\
23 \cdot 83 \\
23 \cdot 22 \\
23 \cdot 65 \\
23 \cdot 04 \\
21 \cdot 53\end{array}$ \\
\hline
\end{tabular}

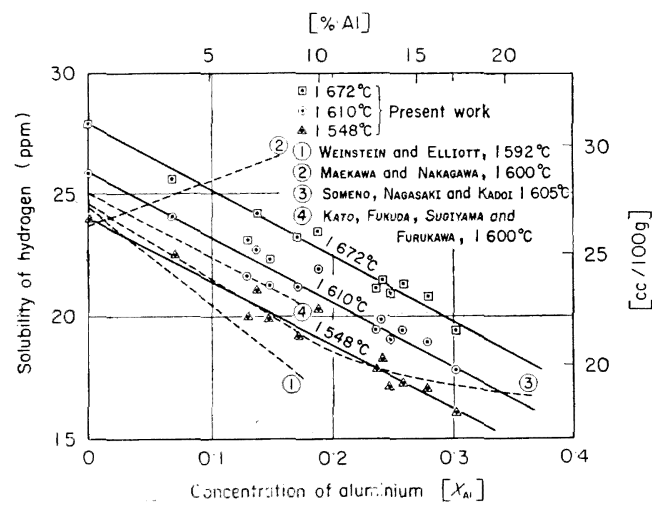

Fig. 1. Solubility of hydrogen in liquid ironaluminium alloys.

度1基集にして，（4)式より溶鉄中水素の活量倸数に およぼすアルミニウムの影響 $\mathrm{f}_{H}^{\mathrm{A} 1}$ を求め，その結果をア ルミニウムの原子分率 $X_{\mathrm{A} 1}$ について図示すれば Fig. 2 のようになる. 同図中には比較のため上述研究者の値を 換算して図示した。 $\log \mathrm{f}_{\mathrm{H}}^{\mathrm{A} 1}$ の温度による变化は，あま り大きくないが，溶解温度の上昇により $\log \mathrm{f}_{\mathrm{H}}^{\mathrm{A} 1}$ の值は 低下する傾向があり，次の近似式で示される．

$$
\cdots \cdots X_{\mathrm{Al}}<0 \cdot 3
$$$$
\log \mathrm{f}_{\mathrm{H}}^{\mathrm{A}}=(1850 / T-0 \cdot 469) X_{\mathrm{A} 1}
$$

上式より LUPIS and ELLIOTT ${ }^{12)}$ の提出した換算式に従 つて相互作用助係数 $e_{\mathrm{H}}^{\mathrm{A}}$, 相互作用母係数 $\varepsilon_{\mathrm{H}}^{\mathrm{A}}$ を求めれ ば次式を得る。

$$
\begin{aligned}
e_{\mathrm{H} 1}^{\mathrm{1}}= & \partial \log \mathrm{f}_{\mathrm{H}} / \partial[\% \mathrm{Al}]=38 \cdot 3 / T-0.0097 \\
& \cdots \cdots \% \mathrm{Al}<10 \quad \cdots \cdots \cdots \cdots \cdots \cdots \cdots \cdots \cdots \cdots \cdots \cdots \cdots \cdots \cdots \cdots \cdots \cdots \cdots \cdots \cdots \\
\varepsilon_{\mathrm{H}}^{\mathrm{A} 1}= & \partial \ln \gamma_{\mathrm{H}} / \partial X_{\mathrm{Al}}=4260 / T-0.563 \\
& \cdots \cdots X_{\mathrm{Al}}<0.3 \quad \cdots \cdots \cdots \cdots \cdots \cdots \cdots \cdots
\end{aligned}
$$

$1600^{\circ} \mathrm{C}$ における著者らの相互作用助係数は $e_{\mathrm{H}}^{A !}=$ 0.0107 であり，これに対して WEINSTEIN and ELLIOTT ${ }^{3)}$

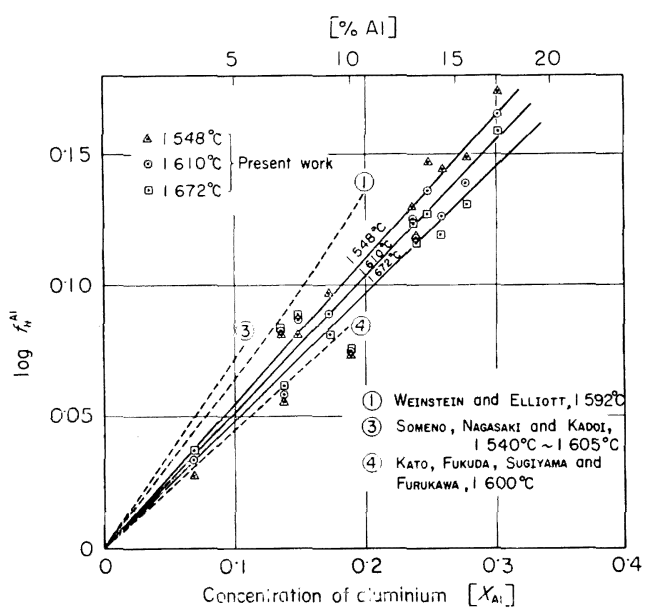

Fig. 2. Effect of aluminium on activity coefficient of hydrogen in liquid iron.

は $1592^{\circ} \mathrm{C}$ で, $e_{\mathrm{H}}^{\mathrm{A} 1}=0 \cdot 013$, 染野ら ${ }^{4)}$ は $e_{\mathrm{B}}^{\mathrm{A}}=0 \cdot 015$, 加 藤ら ${ }^{5)}$ は $e_{\mathrm{H}}^{\mathrm{A} 1}=0.0092$, 前川ら6) は $e_{\mathrm{B}}^{\mathrm{A} 1}=-0.006$ が提出 されており，前川らの值を除けば比較的一致した結果が 得られている.

\subsection{Fe-B 系溶骶合金の水素溶解度}

$\mathrm{Fe}-\mathrm{B}$ 系溶融合金の水素溶解度測定結果を Table 2 お よび Fig. 3 に示す. これより倗素は溶鉄の水素溶解度 を著しく低下せしめ，約 $20 \%$ 硼素で $2 \mathrm{ml} / 100 \mathrm{~g}$ 程度 まで低下することがわかる，鉄硼素系状態図では固体状 態で $\mathrm{F}_{\mathrm{e}_{2}} \mathrm{~B}\left(0.33 X_{\mathrm{B}}, 9 \% \mathrm{~B}\right)$ および $\mathrm{FeB}\left(0.5 X_{\mathrm{B}}, 16 \% \mathrm{~B}\right)$ の金属間化合物が存在するが，その組成附近でとくに大 きい水素溶解度の変化は認められなかつた。本系に関し ては WeINSTEIN and ElliotT ${ }^{3)} の 1592^{\circ} \mathrm{C}$, 嗍素 $6 \%$ $\left(0 \cdot 25 X_{\mathrm{B}}\right)$ までの測定があり，Fig. 3 に見られるように 本研究結果とほぼ一致した結果が得られている。

前述と同様に純鉄側を基準にして水素の活量係数にお 
Table 2. Solubility of hydrogen in iron-boron alloys under an atmospheric pressure.

\begin{tabular}{c|c|c|c|c|c}
\hline \multirow{2}{*}{ Heat No } & \multicolumn{2}{|c|}{ Concentration } & \multicolumn{2}{c}{ Solubility of hydrogen $(\mathrm{m} l / 100 \mathrm{~g})$} \\
\cline { 2 - 5 } & $\%$ B & $X_{\mathrm{B}}$ & $1548^{\circ} \mathrm{C}$ & $1610^{\circ} \mathrm{C}$ & $1672^{\circ} \mathrm{C}$ \\
\hline B 1-1 & $1 \cdot 33$ & $0 \cdot 065$ & $23 \cdot 72$ & $25 \cdot 55$ & $27 \cdot 27$ \\
B 1-2 & $0 \cdot 98$ & $0 \cdot 049$ & 22.83 & $24 \cdot 35$ & $25 \cdot 86$ \\
B 2-2 & $2 \cdot 29$ & $0 \cdot 108$ & $20 \cdot 19$ & $22 \cdot 15$ & $23 \cdot 70$ \\
B 2-3 & $2 \cdot 37$ & $0 \cdot 111$ & $19 \cdot 84$ & $20 \cdot 83$ & $23 \cdot 03$ \\
B 4-1 & $4 \cdot 20$ & $0 \cdot 185$ & $14 \cdot 08$ & $15 \cdot 14$ & $16 \cdot 39$ \\
B 4-2 & $4 \cdot 58$ & $0 \cdot 199$ & $12 \cdot 84$ & $14 \cdot 12$ & $15 \cdot 39$ \\
B 4-3 & $4 \cdot 59$ & $0 \cdot 199$ & $14 \cdot 79$ & $16 \cdot 06$ & $17 \cdot 49$ \\
B 6-1 & $6 \cdot 50$ & $0 \cdot 264$ & $11 \cdot 03$ & $11 \cdot 75$ & $12 \cdot 47$ \\
B 6-2 & $6 \cdot 60$ & $0 \cdot 267$ & $9 \cdot 97$ & $10 \cdot 82$ & $11 \cdot 58$ \\
B 6-3 & $6 \cdot 77$ & $0 \cdot 273$ & $11 \cdot 31$ & $11 \cdot 83$ & $12 \cdot 43$ \\
B 8-1 & $8 \cdot 66$ & $0 \cdot 329$ & $7 \cdot 80$ & $8 \cdot 21$ & $8 \cdot 73$ \\
B 8-3 & $8 \cdot 81$ & $0 \cdot 333$ & $9 \cdot 21$ & $9 \cdot 69$ & $10 \cdot 27$ \\
B 12-1 & $12 \cdot 5$ & $0 \cdot 425$ & $4 \cdot 40$ & $4 \cdot 53$ & $4 \cdot 89$ \\
B 12-2 & $12 \cdot 8$ & $0 \cdot 431$ & $3 \cdot 34$ & $3 \cdot 85$ & $4 \cdot 05$ \\
B 16-2 & $17 \cdot 7$ & $0 \cdot 526$ & $2 \cdot 26$ & $2 \cdot 69$ & $3 \cdot 12$ \\
B 16-3 & $17 \cdot 5$ & $0 \cdot 523$ & $2 \cdot 50$ & $2 \cdot 63$ & 1.83 \\
B 20-3 & $21 \cdot 1$ & $0 \cdot 580$ & $1 \cdot 88$ & $1 \cdot 88$ & $1 \cdot 99$ \\
\hline
\end{tabular}

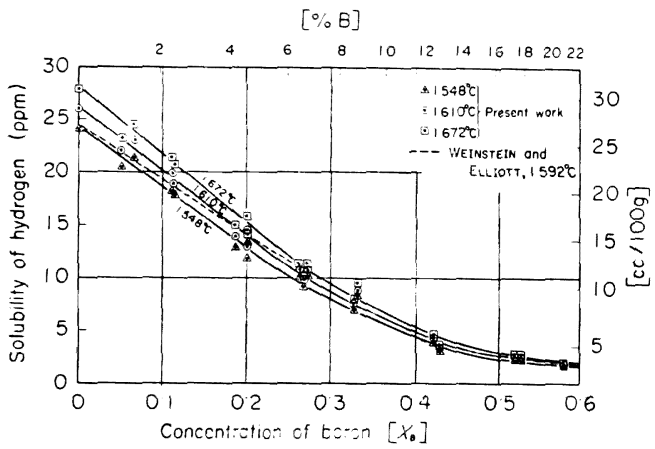

Fig. 3. Solubility of hydrogen in liquid ironboron alloys.

よほす嗍素の影響 $\mathrm{f}_{\mathrm{B}}^{\mathrm{B}}$ を求め, 喼素の原子分率 $X_{\mathrm{B}}$ につ いて図示すれば Fig. 4 のようになり，明りような温度 依存性は見出されず，測定温度範囲 $1540^{\circ} \sim 1670^{\circ} \mathrm{C}$ の 間で次の関係が得られた。

$$
\begin{aligned}
& \log \mathrm{f}_{\mathrm{H}}^{\mathrm{B}}=1 \cdot 13 X_{\mathrm{B}}+1.58 X_{\mathrm{B}}^{2} \cdots \cdots X_{\mathrm{B}}<0.6 \cdots \\
& e_{\mathrm{H}}^{\mathrm{B}}=\partial \log \mathrm{f}_{\mathrm{H}} / \partial[\% \mathrm{~B}]=0.058 \cdots \% \mathrm{~B}<2.5 \\
& \varepsilon_{\mathrm{H}}^{\mathrm{B}}=\partial \ln \gamma_{\mathrm{H}} / \partial X_{\mathrm{B}}=3.41 \cdots \cdots X_{\mathrm{B}}<0.1 \cdots \cdots
\end{aligned}
$$

WeINSTEIN and ElLIOTT ${ }^{3)}$ は $1592^{\circ} \mathrm{C}$ にて $e_{\mathrm{H}}^{\mathrm{B}}=0.050$ を得ており，本研究の結果とよく一致している.

\section{$3.3 \mathrm{Fe}-\mathrm{Ge}$ 系溶融合金の水素溶解度}

$\mathrm{Fe}-\mathrm{Ge}$ 系溶融合金の水素溶解度測定結果を Table 3 に，これを Fig. 5 に困示した. Fe-Ge 合金の水素溶解 度はゲルマこウムの濃度 $X_{\mathrm{Ge}}$ に対してほぼ直線的に低 下する. Fig. 5 中には Weinstein and Elliotis ${ }^{3)}$ と染 野・長崎・門井“らら測定を比較のため図示したが，本 研究の結果は WEINSTEIN and ELLIOTT ${ }^{3)}$ の測定に近い

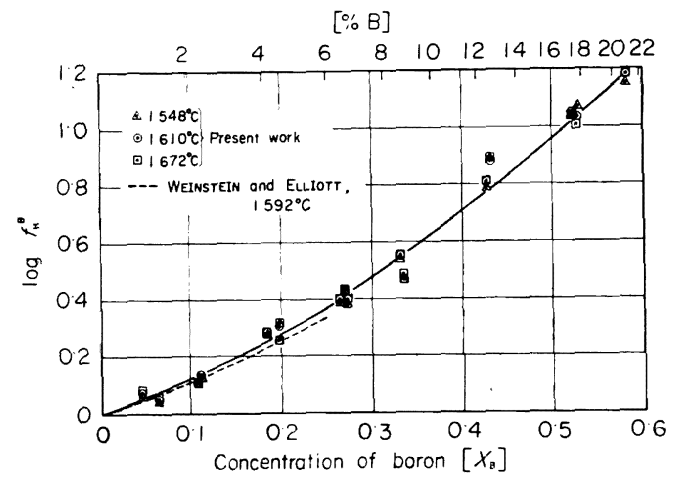

Fig. 4. Effect of boron on activity coefficient of hydrogen in liquid iron.

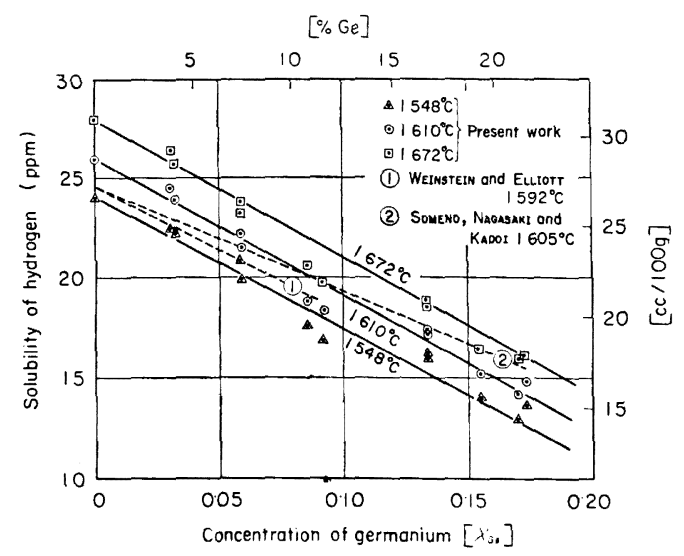

Fig. 5. Solubility of hydrogen in liquid irongermanium alloys. 
Table 3. Solubility of hydrogen in iron-germanium alloys under an atmospheric pressure.

\begin{tabular}{|c|c|c|c|c|c|}
\hline \multirow{2}{*}{ Heat No } & \multicolumn{2}{|c|}{ Concentration } & \multicolumn{3}{|c|}{ Solubility of hydroger $(\mathrm{m} l / 100 \mathrm{~g})$} \\
\hline & $\% \mathrm{Ge}$ & $X_{\mathrm{Ge}}$ & $1548^{\circ} \mathrm{C}$ & $1610^{\circ} \mathrm{C}$ & $1672^{\circ} \mathrm{C}$ \\
\hline $\begin{array}{lr}\mathrm{Ge} & 4-1 \\
\mathrm{Ge} & 4-2 \\
\mathrm{Ge} & 8-1 \\
\mathrm{Ge} & 8-3 \\
\mathrm{Ge} & 12-1 \\
\mathrm{Ge} & 12-3 \\
\mathrm{Ge} & 16-1 \\
\mathrm{Ge} & 16-2 \\
\mathrm{Ge} & 20-1 \\
\mathrm{Ge} & 20-2 \\
\mathrm{Ge} & 20-3\end{array}$ & $\begin{array}{l}4 \cdot 14 \\
3 \cdot 87 \\
7 \cdot 47 \\
7 \cdot 54 \\
11 \cdot 6 \\
10 \cdot 9 \\
16 \cdot 7 \\
16 \cdot 7 \\
21 \cdot 0 \\
19 \cdot 3 \\
21 \cdot 4\end{array}$ & $\begin{array}{l}0 \cdot 032 \\
0 \cdot 030 \\
0 \cdot 058 \\
0 \cdot 059 \\
0 \cdot 092 \\
0 \cdot 086 \\
0 \cdot 134 \\
0 \cdot 134 \\
0 \cdot 170 \\
0 \cdot 155 \\
0 \cdot 173\end{array}$ & $\begin{array}{l}24 \cdot 63 \\
24 \cdot 91 \\
23 \cdot 18 \\
22 \cdot 10 \\
18 \cdot 68 \\
19 \cdot 58 \\
17 \cdot 97 \\
17 \cdot 87 \\
14 \cdot 46 \\
15 \cdot 64 \\
15 \cdot 21\end{array}$ & $\begin{array}{l}26 \cdot 47 \\
27 \cdot 28 \\
24 \cdot 59 \\
23 \cdot 88 \\
20 \cdot 32 \\
20 \cdot 85 \\
19 \cdot 28 \\
19 \cdot 36 \\
15 \cdot 73 \\
16 \cdot 84 \\
16 \cdot 47\end{array}$ & $\begin{array}{l}28 \cdot 55 \\
29 \cdot 29 \\
26 \cdot 39 \\
25 \cdot 75 \\
21 \cdot 95 \\
22 \cdot 85 \\
20 \cdot 59 \\
20 \cdot 85 \\
17 \cdot 76 \\
18 \cdot 21 \\
17 \cdot 81\end{array}$ \\
\hline
\end{tabular}

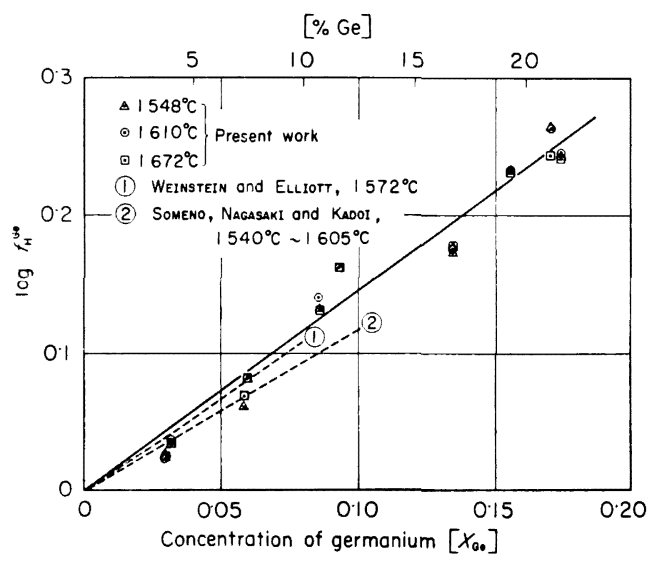

Fig. 6. Effect of germanuim on activity coefficient of hydrogen in liqiud iron.

\section{結果を示している.}

前述と同様に純鉄側を基準にして Fe-Ge 系における 水素の相互作用係数を求めると Fig. 6 のようになり, その直線の勾配より次式を得た.

$\log \mathrm{f}_{\mathrm{H}}^{\mathrm{a} e}=1 \cdot 42 X_{\mathrm{Ge}} \cdots \cdots X_{\mathrm{Ge}}<0 \cdot 2$

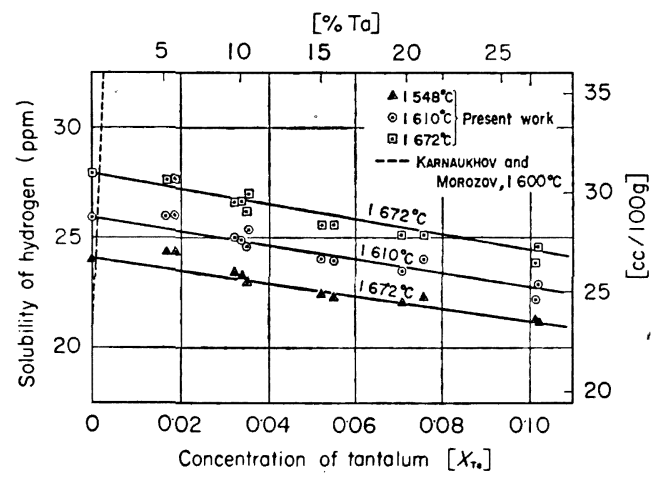

Fig. 7. Solubility of hydrogen in liquid irontantalum alloys.

$e_{\mathrm{H}}^{\mathrm{Ge}}=\partial \log \mathrm{f}_{\mathrm{H}}^{\mathrm{Ge}} / \partial[\% \mathrm{Ge}]=0.0109 \cdots \% \mathrm{Ge}<10 \cdots(12)$

$\varepsilon_{\mathrm{H}}^{\mathrm{Ge}}=\partial \ln \gamma_{\mathrm{H}} / \partial X_{\mathrm{Ge}}=2 \cdot 97 \cdots \cdots X_{\mathrm{Ge}}<0.2$

Weinstein and ElliotT ${ }^{3)} 1592^{\circ} \mathrm{C}$ にて $e_{\mathrm{H}}^{a \mathrm{e}}=0.010$, 染野ら4は $1605^{\circ} \mathrm{C} に て ~ e_{\mathrm{H}}^{\mathrm{ae}}=0.009$ を提出しており, $\mathrm{Ge}=10 \%$ 以下の範囲では三者の測定結果は誤差の範囲 でよく一致している.

Table 4. Solubility of hydrogen in iron-tantalum alloys under an atmospheric pressure.

\begin{tabular}{c|c|c|c|c|c}
\hline \multirow{2}{*}{ Heat No } & \multicolumn{2}{|c|}{ Concentration } & \multicolumn{2}{c}{ Solubility of hydrogen $(\mathrm{m} l / 100 \mathrm{~g})$} \\
\cline { 2 - 5 } & $\% \mathrm{Ta}$ & $X_{\text {Ta }}$ & $1548^{\circ} \mathrm{C}$ & $1610^{\circ} \mathrm{C}$ & $1672^{\circ} \mathrm{C}$ \\
\hline Ta 5-1 & $5 \cdot 80$ & $0 \cdot 019$ & $27 \cdot 05$ & $28 \cdot 89$ & $30 \cdot 74$ \\
Ta 5-2 & $5 \cdot 20$ & $0 \cdot 017$ & $27 \cdot 11$ & $28 \cdot 89$ & $30 \cdot 69$ \\
Ta 10-1 & $10 \cdot 1$ & $0 \cdot 033$ & $25 \cdot 84$ & $27 \cdot 67$ & $29 \cdot 59$ \\
Ta 10-2 & $10 \cdot 5$ & $0 \cdot 035$ & $25 \cdot 54$ & $27 \cdot 34$ & $29 \cdot 06$ \\
Ta 10-4 & $10 \cdot 6$ & $0 \cdot 035$ & $26 \cdot 14$ & $28 \cdot 09$ & $29 \cdot 87$ \\
Ta 10-5 & $9 \cdot 74$ & $0 \cdot 032$ & $26 \cdot 03$ & $27 \cdot 78$ & $29 \cdot 53$ \\
Ta 15-1 & $15 \cdot 9$ & $0 \cdot 055$ & $24 \cdot 88$ & $26 \cdot 65$ & $28 \cdot 38$ \\
Ta 15-2 & $15 \cdot 1$ & $0 \cdot 052$ & $24 \cdot 97$ & $26 \cdot 68$ & $28 \cdot 39$ \\
Ta 20-1 & $19 \cdot 8$ & $0 \cdot 071$ & $24 \cdot 59$ & $26 \cdot 12$ & $27 \cdot 83$ \\
Ta 20-2 & $27 \cdot 0$ & $0 \cdot 076$ & $24 \cdot 81$ & $26 \cdot 63$ & $28 \cdot 45$ \\
Ta 25-1 & $26 \cdot 9$ & $0 \cdot 102$ & $23 \cdot 65$ & $24 \cdot 61$ & $26 \cdot 54$ \\
Ta 25-2 & $26 \cdot 9$ & $0 \cdot 102$ & $23 \cdot 62$ & $25 \cdot 43$ & $27 \cdot 24$ \\
\hline
\end{tabular}




\subsection{Fe-Ta 系溶融合金の水素溶解度}

$\mathrm{Fe}-\mathrm{Ta}$ 系溶融合金の水素溶解度測定結果をTable 4 お よび Fig. 7 に示す.本系の水素溶解度は測定範囲 $0 \cdot 1 X_{\mathrm{Ta}}$ (約 $27 \% \mathrm{Ta}$ ) まで直線的に減少する.また KARNAUKHOV and Morozov ${ }^{7)}$ は Fig. 7 中点線で示すように，タンタ ルは水素溶解度を著しく増加せしめると報告している. しかし，KARNAUKHOV and MOROzOV ${ }^{7)}$ の測定結果は $\mathrm{Fe}-\mathrm{Nb}$ 系, $\mathrm{Fe}$ - $\mathrm{Ti}$ 系においても最近の測定結果と著し く異なつた值を提出しており，本系についても疑問がも たれる。

前述と同様に，純鉄側を基準にして $\mathrm{Fe}-\mathrm{Ta}$ 系におけ る水素の相互作用係数を求めて図示すれば Fig. 8 のよう になる．鉄中水素の活量係数におよぼすタンタルの影響 は，他の元素に比較して小さく，それゆえFig. 8 の縦軸 の目盛が大きくとられているため測定値は多少分散して いるが，これらより次の結果を得た

$\log \mathrm{f}_{\mathrm{H}}^{\mathrm{Ta}}=0 \cdot 56 X_{\mathrm{T}}$

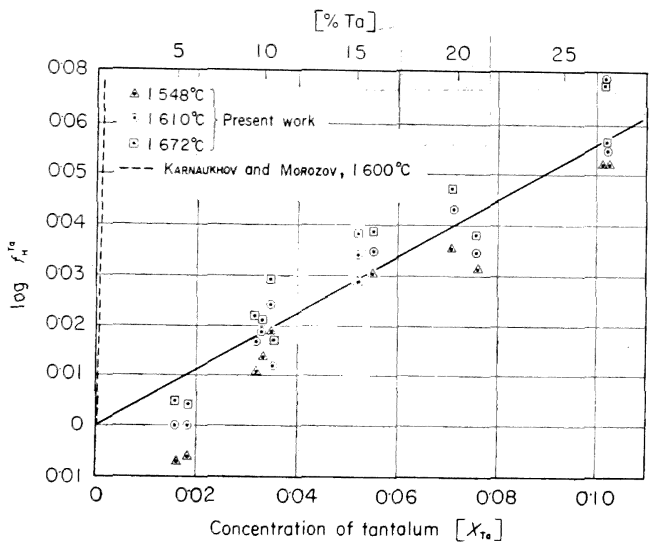

Fig. 8. Effect of tantalum on activity coefficent of hydrogen in liquid iron.

$$
\begin{aligned}
& e_{\mathrm{H}}^{\mathrm{Ta}_{\mathrm{a}}}=\partial \log \mathrm{f}_{\mathrm{H}} / \partial[\% \mathrm{Ta}]=0.0017 \cdots \% \mathrm{Ta}<25 \cdots(15) \\
& \varepsilon_{\mathrm{H}}^{\mathrm{Ta}_{\mathrm{a}}}=\partial \ln \gamma_{\mathrm{H}} / \partial X_{\mathrm{Ta}}=-0.96 \cdots \cdots \cdots X_{\mathrm{Tu}}<0 \cdot 1 \cdots(16)
\end{aligned}
$$

Karnaukhov and Morozovis)らの $1600^{\circ} \mathrm{C}$ におけ る相互作用助係数は $e_{\mathrm{H}}^{\mathrm{Ta}}=-0 \cdot 26^{8)}$ であり. 測定上の䛊 りではないかと思われる.

\section{$3.5 \mathrm{Fe}-\mathrm{Sn}$ 系溶融合金の水素溶解度}

$\mathrm{Fe}-\mathrm{Sn}$ 系溶融合金の水素溶解度測定結果を Table 5 お よび Fig. 9 に示す. 高温度において錫は蒸気圧が高く, 溶解前後における錫の蒸発損失量は測定条件により 30 $70 \%$ におよぶ. また化学分析の結果もあまり再現性は よくなかつた、それゆえ合金中錫の組成は配合量と蒸発 損失減量より計算によつて求めた。したがつて，錫の組 成には最大 $10 \%$ 程度の誤差があると考元ら机, 十分精度 の高い結果とはい兑ないが，測定範罒 $0 \cdot 1 X_{\mathrm{Sn}}(18 \% \mathrm{Sn})$ までほぼ直線的に水素溶解度は減少する。 Fig. 9 より わかるように，約6\% 錫まで測定した染野・長崎・門井 ら4)と，WEINSTEIN and ELLIOTT”の測定結果も同様の 傾向を示している.

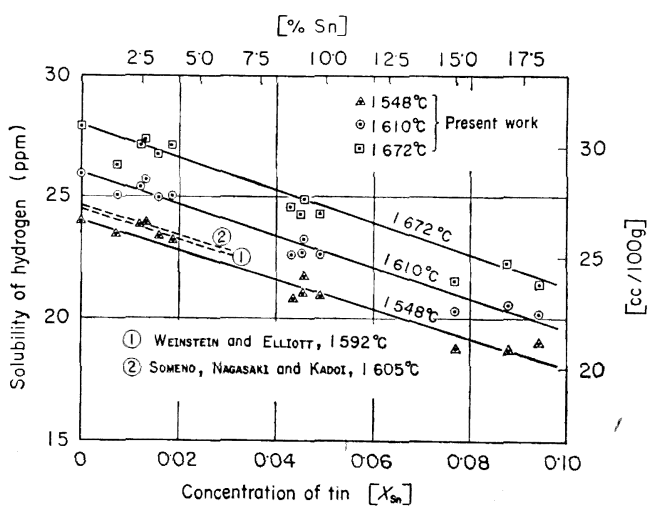

Fig. 9. Solubility of hydrogen in liquid iron-tin alloys.

Table 5. Solubility of hydrogen in iron-tin alloys under an atmospheric pressure.

\begin{tabular}{c|c|c|c|c|c}
\hline \multirow{2}{*}{ Heat No } & \multicolumn{2}{|c|}{ Concentration } & \multicolumn{2}{c}{ Solubility of hydrogen $(\mathrm{m} l / 100 \mathrm{~g})$} \\
\cline { 2 - 5 } & $\%$ Sn & $X_{\text {Sn }}$ & $1548^{\circ} \mathrm{C}$ & $1610^{\circ} \mathrm{C}$ & $1672^{\circ} \mathrm{C}$ \\
\hline Sn 5-1 & $1 \cdot 5$ & $0 \cdot 007$ & $26 \cdot 06$ & $27 \cdot 87$ & $29 \cdot 22$ \\
Sn 5-2 & $2 \cdot 5$ & $0 \cdot 012$ & $26 \cdot 48$ & $28 \cdot 19$ & $30 \cdot 07$ \\
Sn 5-3 & $2 \cdot 1$ & $0 \cdot 013$ & $26 \cdot 59$ & $28 \cdot 53$ & $30 \cdot 30$ \\
Sn 10-2 & $3 \cdot 3$ & $0 \cdot 016$ & $25 \cdot 95$ & $27 \cdot 77$ & $29 \cdot 70$ \\
Sn 10-3 & $3 \cdot 9$ & $0 \cdot 019$ & $25 \cdot 77$ & $27 \cdot 81$ & $30 \cdot 21$ \\
Sn 15-1 & $9 \cdot 3$ & $0 \cdot 046$ & $24 \cdot 17$ & $25 \cdot 81$ & $27 \cdot 64$ \\
Sn 15-2 & $8 \cdot 8$ & $0 \cdot 043$ & $23 \cdot 19$ & $25 \cdot 13$ & $27 \cdot 31$ \\
Sn 15-3 & $9 \cdot 2$ & $0 \cdot 046$ & $23 \cdot 35$ & $25 \cdot 24$ & $26 \cdot 99$ \\
Sn 15-4 & $9 \cdot 9$ & $0 \cdot 049$ & $23 \cdot 23$ & $25 \cdot 11$ & $26 \cdot 99$ \\
Sn 20-3 & $15 \cdot 0$ & $0 \cdot 077$ & $20 \cdot 85$ & $22 \cdot 49$ & $23 \cdot 90$ \\
Sn 25-3 & $17 \cdot 0$ & $0 \cdot 088$ & $20 \cdot 82$ & $22 \cdot 80$ & $24 \cdot 78$ \\
\end{tabular}


$[\% \mathrm{Sn}]$

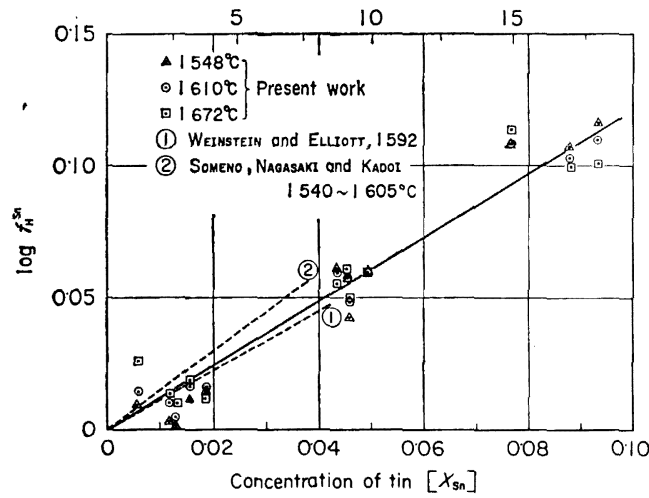

Fig. 10. Effect of tin on activity coefficient of hydrogen in liquid iron.

これらの結果より相互作用係数を求めれば Fig. 10 の ようになり，次式が得られた。

$\log \mathrm{f}_{\mathrm{H}}^{\mathrm{Sn}}=1 \cdot 2 X_{\mathrm{Sn}} \cdots \cdots \cdots \cdots \cdots X_{\mathrm{Sn}}<0 \cdot 1 \cdots \cdots(17)$
$e_{\mathrm{H}}^{\mathrm{Sn}}=\partial \log \mathrm{f}_{\mathrm{H}} / \partial[\% \mathrm{Sn}]=0 \cdot 0057 \ldots \% \mathrm{Sn}<7 \cdots(18)$
$\varepsilon_{\mathrm{H}}^{S_{n}}=\partial \ln \gamma_{\mathrm{H}} / \partial X_{\mathrm{Sn}}=1 \cdot 7 \cdots \cdots \cdots \cdots X_{\mathrm{Sn}}<0 \cdot 1 \cdots(19)$

なお相互作用助係数として WEINSTEIN and ELLIOTT ${ }^{3)}$ は $1592^{\circ} \mathrm{C}$ で $e_{\mathrm{H}}^{\mathrm{Sn}}=0.0053$, 染野ら") $1605^{\circ} \mathrm{C}$ にて $e_{\mathrm{H}}^{\mathrm{Sn}}=0.007$ を提出している.

\subsection{Fe-Zr 系溶虽合金の水素溶解度}

$\mathrm{Fe}-\mathrm{Zr}$ 系溶融合金の水素溶解度測定結果を Table 6 お よび Fig. 11 に示す. 本系の測定では溶鉄表面に酸化物 と思われる scum が生成し，とくにジルコニウム濃度 が高くなると著しく，温度測定に困難があつた，したが つて，測定範囲は 7\% Zr までに止めた. ジルコニウム はチタンと並んで化学的に活性な元素であり, Fig. 11 に 見られるように水素溶解度を著しく上昇せしめる。

これらの結果より相互作用係数を求めて図示すれば Fig. 12 のようになり， $\log \mathrm{f}_{\mathrm{H}}^{z r}$ には溶解温度による相違 が認められ，次式によつて示される.

$\log \mathrm{f}_{\mathrm{H}}^{\mathrm{Zr}_{\mathrm{r}}}=(-12500 / T+5 \cdot 24) X_{\mathrm{Z}_{\mathrm{r}}} \cdots X_{\mathrm{Zr}_{\mathrm{r}}}<0 \cdot 1 \cdots(20)$

$e_{\mathrm{H}}^{\mathrm{Zr}}=\partial \log f_{\mathrm{H}} / \partial[\% \mathrm{Zr}]=-76 \cdot 5 / T+0 \cdot 0321$

$$
\% \mathrm{Zr}<2
$$

$\varepsilon_{\mathrm{H}}^{\mathrm{Z}_{\mathrm{r}}}=\partial \ln \gamma_{\mathrm{H}} / \partial X_{\mathrm{Zr}}=-28800 / T+11 \cdot 43$

$$
\cdot X_{\mathrm{Zr}}<0 \cdot 1
$$

これより本測定結果における $1600^{\circ} \mathrm{C}$ の相互作用助 係数は $e_{\mathrm{B}}^{\mathrm{Zr}}=-0.0088, \varepsilon_{\mathrm{H}}^{\mathrm{Zr}}=-3.94$ であり，ジルコニウ ムは非常に大きく溶鉄の水素溶解度を増加せしめること がわかる。

\section{4. 考察}

以上 6 種の 2 元系鉄合金について，可能なかきり広い 濃度範囲にわたり，水素1気圧下における水素溶解度を 測定して，これより溶鉄中水素の活量係数におよぼす合 金元素の影響を求めた. $1600^{\circ} \mathrm{C}$ におるこれらの結果 を総括し, 他の研究者との比較を Table 7 に示す. こ れより, 著者らの結果も含め, 最近の測定結果はほほ一 致していることがわかる.

以上の結果および著者らがこれまで測定してきた 18

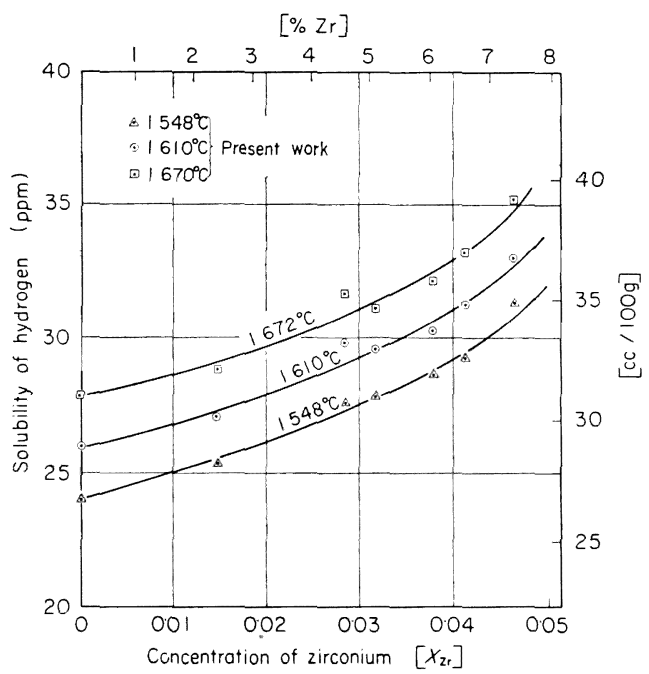

Fig. 11. Solubility of hydrogen in liquid ironzirconium alloys.

\begin{tabular}{|c|c|c|c|c|c|}
\hline \multirow{2}{*}{ Heat No } & \multicolumn{2}{|c|}{ Concentration } & \multicolumn{3}{|c|}{ Solubility of hydrogen $(\mathrm{ml} / 100 \mathrm{~g})$} \\
\hline & $\% \mathrm{Zr}$ & $X_{Z \mathbf{r}}$ & $1548^{\circ} \mathrm{C}$ & $1610^{\circ} \mathrm{C}$ & $1672^{\circ} \mathrm{C}$ \\
\hline $\begin{array}{lr}\mathrm{Zr} & 8-4 \\
\mathrm{Zr} & 10-5 \\
\mathrm{Zr} & 10-3 \\
\mathrm{Zr} & 10-2 \\
\mathrm{Zr} & 10-4 \\
\mathrm{Zr} & 10-1\end{array}$ & $\begin{array}{l}2 \cdot 39 \\
4 \cdot 57 \\
5 \cdot 07 \\
6 \cdot 05 \\
6 \cdot 56 \\
7 \cdot 40\end{array}$ & $\begin{array}{l}0 \cdot 015 \\
0 \cdot 028 \\
0 \cdot 032 \\
0 \cdot 038 \\
0 \cdot 041 \\
0 \cdot 047\end{array}$ & $\begin{array}{l}28 \cdot 18 \\
30 \cdot 67 \\
30 \cdot 99 \\
31 \cdot 87 \\
32 \cdot 59 \\
34 \cdot 50\end{array}$ & $\begin{array}{l}30 \cdot 11 \\
33 \cdot 14 \\
32 \cdot 85 \\
33 \cdot 61 \\
34 \cdot 78 \\
36 \cdot 84\end{array}$ & $\begin{array}{l}32 \cdot 04 \\
35 \cdot 14 \\
34 \cdot 62 \\
35 \cdot 73 \\
36 \cdot 98 \\
39 \cdot 18\end{array}$ \\
\hline
\end{tabular}

Table 6. Solubility of hydrogen in iron-zirconium alloys under an atmospheric pressure. 


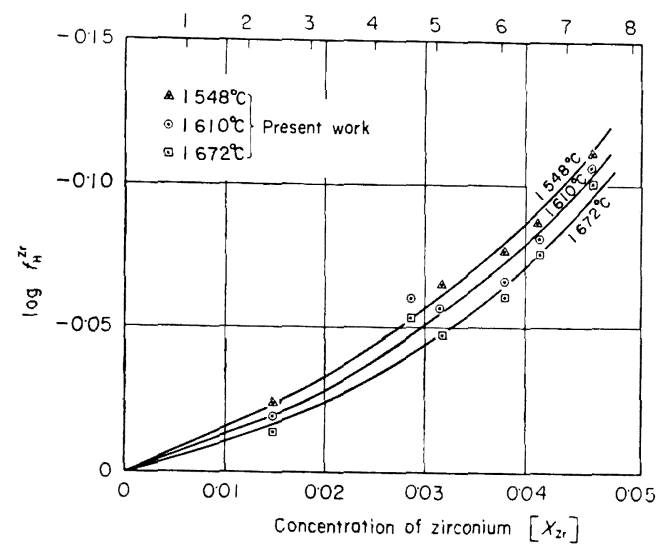

Fig. 12. Effect of zirconium on activity coefficient of hydrogen in liquid iron.

元素について, 溶鉄への水素溶解度におよぼす各種合金 元素の影響をまとめて眓示すれば Fig. 13 のようにな

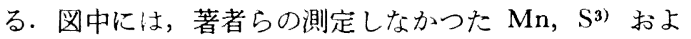
び $\mathrm{Be}^{4}$ の結果についても他の研究者の值を換算して点線 で示した. 同様の関係を相互作用助係数と合金元素の重 量百分率で示せば Fig. 14 のようになる. これより一般 に化学的に活性で水素との化学親和力の強い元素ほど水 素溶解度をより大きく増加せしめる傾向があり, 後述す るように, 水素溶解度の増減と合金元素の物理化学的性 質との間には密接な関連性のあることが推測される.

最近溶鉄中硫黄, 炭素, 室素などの活量係数におよぼ す合金元素の影響について多くの研究報告が提出され，
これらの測定値より未測定元素の值を推測する方法とし て,相互作用母係数と元素周期律表との関連性, effective free electron との関連性, 類似元素との比較などが活発 に行なわれている。 $\mathrm{Fe}-\mathrm{H}-\mathrm{j} 3$ 元系に㧍ける相互作用母 係数と元素周期律表との関連については OHTANI and

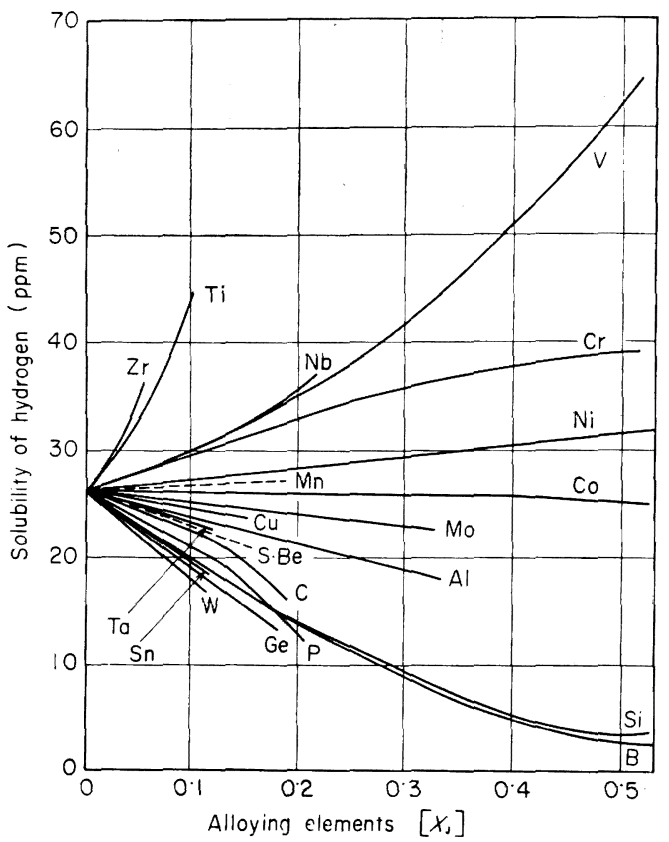

Fig. 13. Effect of alloying elements on the solubility of hydrogen in liquid iron at $1610^{\circ} \mathrm{C}$.

Table 7. Interaction parameter of hydrogen in liquid iron at $1600^{\circ} \mathrm{C}$.

\begin{tabular}{|c|c|c|c|c|c|}
\hline Element & Investigators & Ref & $e_{\mathrm{H}}^{\jmath}$ & Range & $\varepsilon$ 㟧 \\
\hline $\mathrm{Al}$ & $\begin{array}{l}\text { Weinstein, Elliott } \\
\text { MaEkawa, NaKaGaWa } \\
\text { Someno, Nagasaki, Kadoi } \\
\text { Kato, Fukuda, Sugiyama, Furukawa } \\
\text { Present work }\end{array}$ & $\begin{array}{l}3 \\
6 \\
4 \\
5\end{array}$ & $\begin{aligned} 0 \cdot 013 \\
-0 \cdot 006 \\
0 \cdot 015 \\
0 \cdot 0093 \\
0 \cdot 0107\end{aligned}$ & $\begin{array}{l}<11 \% \mathrm{Al} \\
<6 \% \mathrm{Al} \\
<6 \% \mathrm{Al} \\
<10 \% \mathrm{Al}\end{array}$ & $\begin{array}{l}1 \cdot 96 \\
0 \cdot 15 \\
2 \cdot 19 \\
1 \cdot 54 \\
1 \cdot 71\end{array}$ \\
\hline B & $\begin{array}{l}\text { Weinstein, ElliotT } \\
\text { Present work }\end{array}$ & 3 & $\begin{array}{l}0 \cdot 050 \\
0 \cdot 058\end{array}$ & $\begin{array}{l}<2 \cdot 2 \% \mathrm{~B} \\
<2 \cdot 5 \% \mathrm{~B}\end{array}$ & $\begin{array}{l}3 \cdot 04 \\
3 \cdot 41\end{array}$ \\
\hline $\mathrm{Ge}$ & $\begin{array}{l}\text { Weinstein, ElliotT } \\
\text { Someno, Nagasaki, Kadoi } \\
\text { Present work }\end{array}$ & $\begin{array}{l}3 \\
4\end{array}$ & $\begin{array}{l}0 \cdot 010 \\
0 \cdot 009 \\
0 \cdot 0109\end{array}$ & $\begin{array}{l}<11 \% \mathrm{Ge} \\
<15 \% \mathrm{Ge} \\
<10 \% \mathrm{Ge}\end{array}$ & $\begin{array}{l}2 \cdot 69 \\
2 \cdot 40 \\
2 \cdot 97\end{array}$ \\
\hline $\mathrm{Ta}$ & $\begin{array}{l}\text { KARNAUKHOV, MOROzOV } \\
\text { Present work }\end{array}$ & 7 & $\begin{array}{l}-0 \cdot 26 \\
0 \cdot 0017\end{array}$ & $<25 \% \mathrm{Ta}$ & $\begin{array}{l}-196 \\
-0 \cdot 96\end{array}$ \\
\hline Sn & $\begin{array}{l}\text { Weinstein, ElliotT } \\
\text { Someno, NAGASAKI, KadOI } \\
\text { Present work }\end{array}$ & $\begin{array}{l}3 \\
4\end{array}$ & $\begin{array}{l}0 \cdot 0053 \\
0 \cdot 007 \\
0 \cdot 0057\end{array}$ & $\begin{array}{l}<6 \% \mathrm{Sn} \\
<6.5 \% \mathrm{Sn} \\
<7 \% \mathrm{Sn}\end{array}$ & $\begin{array}{l}1 \cdot 48 \\
2 \cdot 31 \\
1 \cdot 7\end{array}$ \\
\hline $\mathrm{Zr}$ & Present work & & $-0 \cdot 0088$ & $<2 \% \mathrm{Zr}$ & $-3 \cdot 94$ \\
\hline
\end{tabular}




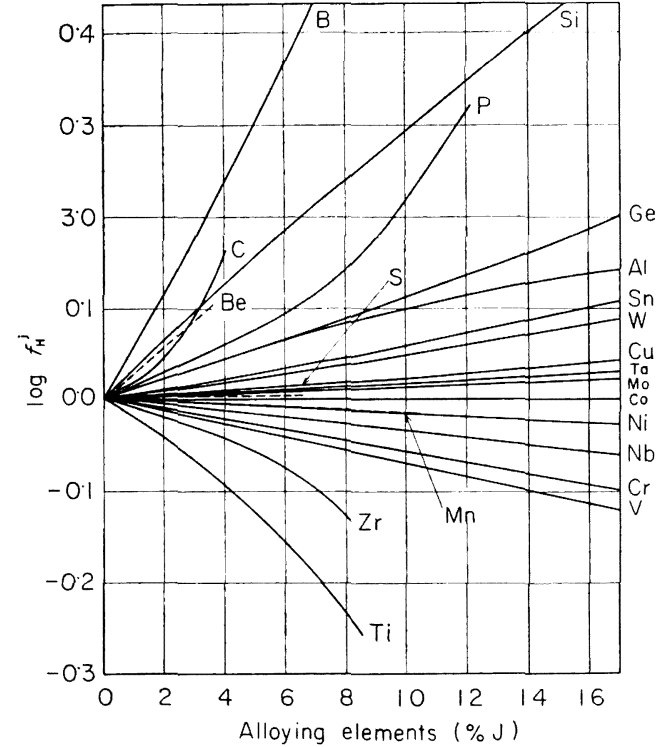

Fig. 14. Effect of alloying elements on activity coefficient of hydrogen in iron at $1600^{\circ} \mathrm{C}$.

GOKCEN9) により試みられているが，著者らの測定結果
をまとめて示すと Fig. 15 のようになる、図中黒丸は著 者らの測定值を, 各元素の範囲はこれまでの他の測定結 果を示している，Fe-H-j 系の場合には，これまで報告 されている Fe-C-j 系や Fe-N-j 系のようなきれいな関 連性はないが，全体として相互作用母係数と元素周期律 表との間にかなりの関連性のあることがわかる．各元素 の物理化学的性質は元素の周期律表と密接な関係があり 相互作用母係数もまた規則的変化を示していることがう かがわれる

Effective free electron との関連性については, $C$. WAGNER の合金中における elcetronic structure を考慮 した考え方を利用した WEINSTEIN and ELLIOTT" ${ }^{3)}$ の報告 がある.これによれば effective free electron と相互作 用母係数との間には一定の関係があり, 同一 effective free electron 数をもつ元素は近似的に同程度の相互作用 母係数を示すとしている. したがつて, 元素周期律表上 同族の元素は近似の相互作用母係数を示すことになる. しかし，Fig. 15 より明らかなように，第 VI a 族の $\mathrm{Cr}$, $\mathrm{Mo}, \mathrm{W}$ ，第 II b 族 $\mathrm{B} ， \mathrm{Al}$ ，第 $\mathrm{IV} \mathrm{b}$ 族 $\mathrm{C} ， \mathrm{Si}, \mathrm{Ge}, \mathrm{Sn} な$ どは必ずしも一定の值を示していない. WEINSTEIN and

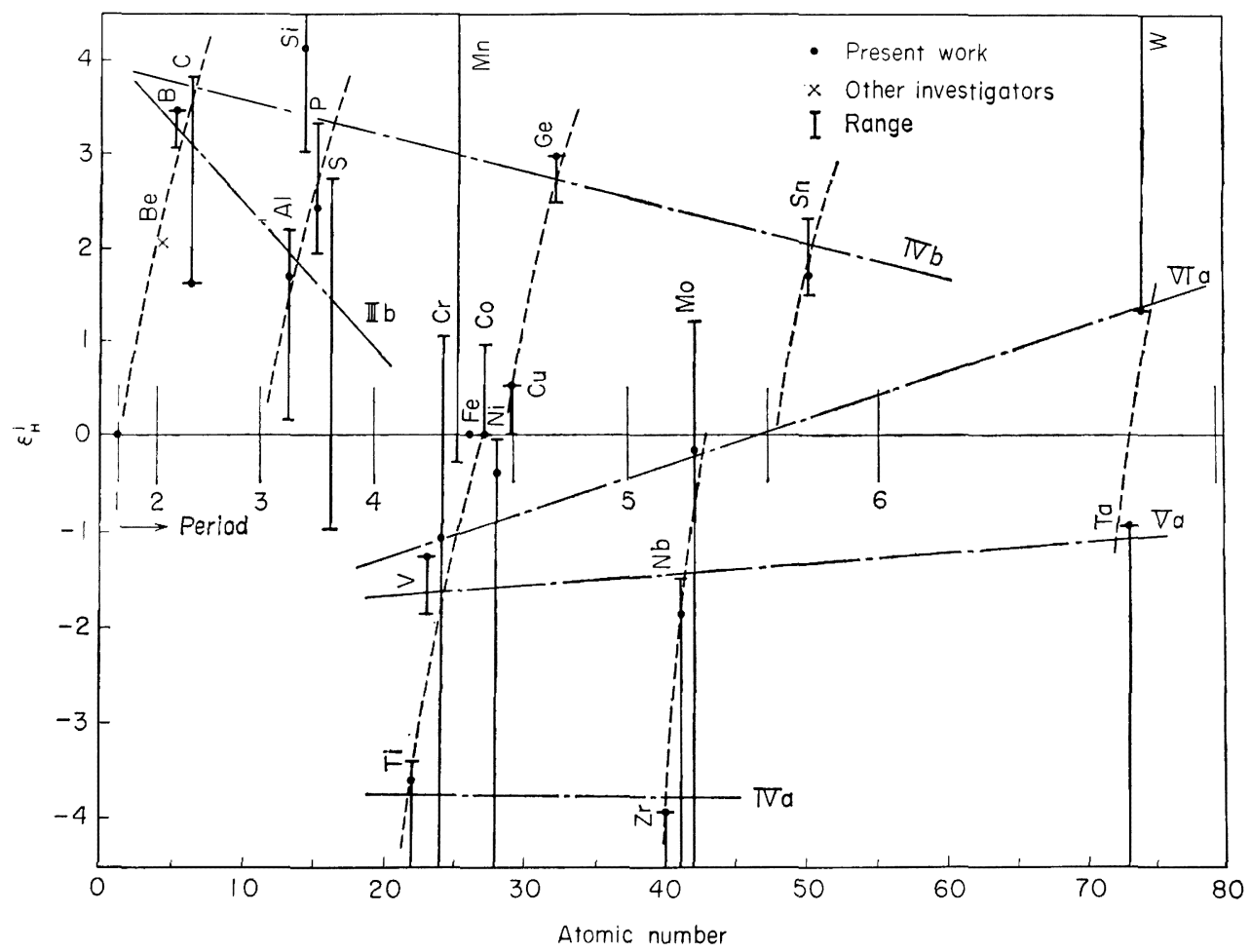

Fig. 15. Relation between atomic number and interaction parameter of hydrogen in liquid alloys at $1600^{\circ} \mathrm{C}$. 
ELLIOTT $^{3)}$ の研究は主として第 3 および第 4 周期の元素 を測定したものであり，Fig. 15 中 $\mathrm{Ti}$ より Ge にいた る関係と $\mathrm{Al}$ より $\mathrm{S}$ にたる関係を同一曲線で結えだも ので，多くの元素についてはあてはまらないものと思わ れる.一般に溶液中の元素の活量は, 溶液中の各成分間 の相互作用, 溶液の構造, 原子半径などによつて左右さ れ, 単に effective free electron 数のみから多くの元素 に共通な関係を律することは十分とは考えられない。

つぎに相互作用母係数の温度依存性について 2,3 の 計算を示す．今，無限希薄溶液を基準にすれば，溶鉄人 の水素溶解の自由エネルギー変化は次式により求められ る.

$$
\begin{aligned}
& 1 / 2 \mathrm{H}_{2}(\mathrm{~g})=\mathrm{H} \text { (in liquid alloys) } \\
& J G_{\mathrm{H}}=R T \ln a_{\mathrm{H}}=R T \ln X_{\mathrm{H}}+\Delta G_{\mathrm{H}}^{\mathrm{EX}}
\end{aligned}
$$

ここで $J G_{\mathrm{H}}^{\mathrm{EX}}$ は過剩部分モル自由エネルギーであり, 相互作用母係数より次式によつて求められる.

$$
\Delta G_{\mathrm{H}}^{\mathrm{Ex}}=R T \ln \gamma_{\mathrm{H}}^{\mathrm{j}}=R T \varepsilon_{\mathrm{H}}^{\mathrm{j}} X_{\mathrm{J}} .
$$

したがつて過剩部分モルェンタルピー $\Delta H_{\mathrm{H}}^{\mathrm{EX}}$ および 過剰部分モルエントロピー $\Delta S_{\mathrm{H}}^{\mathrm{Ex}}$ は次式のようになる.

$$
\begin{aligned}
& \Delta H_{\mathrm{H}}^{\mathrm{EX}}=\frac{\partial\left(\Delta G_{\mathrm{H}}^{\mathrm{EX}} / T\right)}{\partial(1 / T)}=\frac{\partial\left(R T \ln \gamma_{\mathrm{H}}^{\mathrm{j}} / T\right)}{\partial(1 / T)} \\
& =R X_{\mathrm{j}} \frac{\partial \varepsilon_{\mathrm{H}}^{\jmath}}{\partial(1 / T)} \\
& -J S_{\mathrm{H}}^{\mathrm{EX}}=\frac{\partial J G_{\mathrm{H}}^{\mathrm{EX}}}{\partial T}=\frac{\partial\left(R T \ln \gamma_{\mathrm{H}}^{\prime}\right)}{\partial T} \\
& =R X_{\mathrm{j}} \frac{\partial\left(T \varepsilon_{\mathrm{H}}^{\mathrm{j}}\right)}{\partial T}
\end{aligned}
$$

それゆえ相互作用母係数 $\varepsilon_{\mathrm{H}}^{j}$ が合金元素の濃度 $X_{\mathrm{j}}$ に 無関係に一定の範囲, 寸なわち希薄溶液では次の関係が 成立する.

$$
\left(\frac{\partial \Delta H_{\mathrm{H}}^{\mathrm{EX}}}{\partial X_{\mathrm{j}}}\right)_{X \mathrm{~F} \leftrightarrow \rightarrow 1}=\eta \mathrm{H},\left(\frac{\partial\lrcorner S_{\mathrm{H}}^{\mathrm{EX}}}{\partial X_{\mathrm{j}}}\right)_{X \mathrm{Fe}_{\mathrm{e}} \rightarrow 1}=\sigma \mathrm{H}
$$

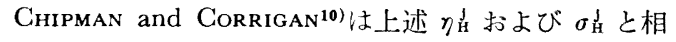
互作用母係数との間には一定の関係があることを指摘し た. 著者らの測定は $1548^{\circ} \sim 1672^{\circ} \mathrm{C}$ の間で行なわれ, 合金元素により測定の正確度も異なり，相互作用母係数 の温度依存性の明らかな系と，不明りような系があるが 明りような温度依存性を示した $\mathrm{C}, \mathrm{Al}, \mathrm{Ni}, \mathrm{V}, \mathrm{No}$, Ti および Zr について上記の計算を行なつた. このよ

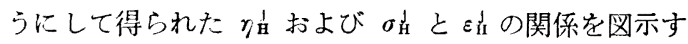
ると Fig. 16 のようになる. すなわち ChIPMAN ら ${ }^{1011)}$ が指摘したように両者の間には大体直線関係が成立し， 水素溶解度を大きく变化せしめる元素ほど, 溶解熱を大 きく变化せしめることがわかる. Fig. 16 の直線関係は

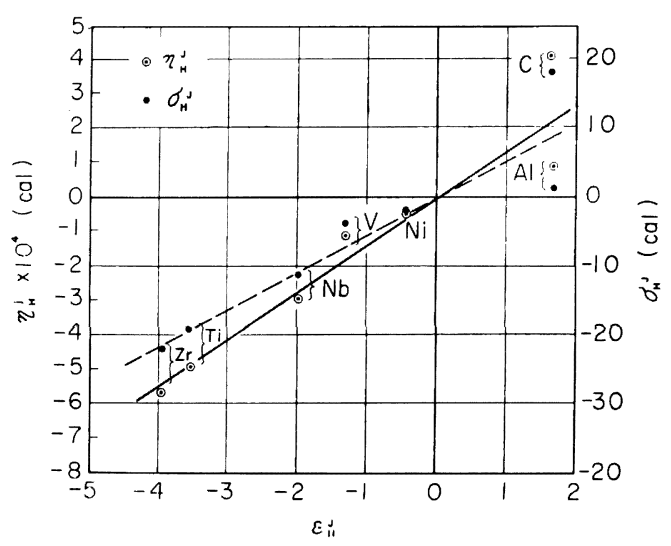

Fig. 16. Relation between enthalpy, entropy and interaction parameter of hydrogen in liquid iron alloys at $1600^{\circ} \mathrm{C}$.

次式によつて示される.

$$
\begin{aligned}
& \eta_{\mathrm{H}}^{J}=1 \cdot 38 \times 10^{4} \varepsilon_{\mathrm{H}}^{\jmath}(\mathrm{cal}) \\
& \sigma_{\mathrm{H}}^{\jmath}=5 \cdot 5 \varepsilon_{\mathrm{H}}^{\jmath}\left(\mathrm{cal} /{ }^{\circ} \mathrm{K}\right) .
\end{aligned}
$$

しかし上記の值は比較的少数の元素より求めたもので あり, $\mathrm{Fe}-\mathrm{H}-\mathrm{j} 3$ 元素のすべてに適合するかどうかは， 今後さらに広い温度範囲にわたつて, より精度の高い測 定が必要である.

\section{5. 結}

\section{言}

以上 $\mathrm{Al}, \mathrm{B}, \mathrm{Ge}, \mathrm{Ta}, \mathrm{Sn}$ おび $\mathrm{Zr}$ の各元素を含む 2 元系溶融合金の水素溶解度を $1548^{\circ} \sim 1672^{\circ} \mathrm{C}$ の範 囲で，また合金組成については可能な範囲で広い濃度範 囲について測定し，これより溶鉄中水素の活量係数にお よぼす合金元素の影響を求めた. これらの結果は Table 7のようになるまたこれまで著者らが行なつてきた $\mathrm{Fe}-\mathrm{H}-\mathrm{j} 3$ 元系のすべての結果 ${ }^{1) 2)}$ を総括し，各元素間の 比較, 元素周期律表との関連性, 溶解熱などにつき若千 の考察を試みた.

終わりに当たり，学生時代に本研究遂行に協力した日 本鋼管 (株) 橘克彦工学士, 川崎製鉄 (株) 芹沢保交工学士 および東北大学工学部石井不二夫工学士および菅原邦男 氏，有益な助言を賜わりました日立金属(株)小野健二博 七の諸氏に深く感謝いたします.

\section{文献}

1) 野崎洋彦, 萬谷志郎, 不破祐, 的場幸雄, 小野健 二: 鉄と鋼, 52 (1966), p.1 823

2 ) 萬谷志郎, 不破祐, 小野健二: 鉄と鋼, 53 (1967), p. 101

3) $M$. Weinstein and $J . F$. Elliott : Trans. Met. 
Soc., AIME., 227 (1963), p. 382

4 ) 染野蕰, 長崎久弥, 門井邦夫 : 日本金属学会誌, 31 (1967), p. 729

5 ) 加藤栄一, 福田重美, 相山隆安, 古川武: 鉄と鋼, $56(1970)$, p. 521

6 ) 前川静弥, 中川義隆：日本金属学会誌, 25 (1961), p. 573 , p. 577

7) M. M. Karnaukhov and $A . N$. Morozev : Izvest. Akad. Nauk SSSR Oted. Nauk, (1948) p. 1845

8) R. G. WARD : An Introduction to the Physical
Chemistry of Iron and Steel Making, (1962), Edward Arnold Ltd. (London)

$9)$ ) Ohtani and $N$. A. Gokcen : Trans. Met. Soc., AIME., 218 (1963), p. 533

10) $J$. Chipman and D. A. Corrigan : Application of Fundamental Thermodynamics to Metallurgical Process, (1967), p. 23

11) J. Chipman : 鉄と鋼, 51 (1965), p. 1477

12) C. H. P. Lupis and $J . F$. Elliott : Trans. Met, Soc., AIME., 233 (1965), p. 257 